\title{
PENGEMBANGAN SOCIAL SKILL SISWA SEKOLAH DASAR MELALUI TEKNIK PEMBELAJARAN VCT (VALUE CLARIFICATION TECHNIQUE
}

\section{Putri Rachmadyanti, Rochani}

Universitas Negeri Surabaya

Universitas Negeri Malang

Sejarah Artikel

Diterima 1 September 2017

Disetujui 1 Oktober 2017

Diterbitkan 1 Desember 2017

\section{Kata Kunci}

VCT, keterampilan sosial, siswa, Sekolah Dasar

\begin{abstract}
Abstrak
Pendidikan Dasar memegang peranan kuat dalam memberikan pondasi kognitif, afektif dan psikomotor bagi siswa. Domain- domain tersebut akan mengantarkan siswa untuk hidup dan berkembang di masyarakat. Namun, kenyataannya beberapa kasus pembelajaran masih menganggap aspek kognitif yang paling utama dikembangkan di Sekolah Dasar, dan kurang mengembangkan kepekaan atau keterampilan sosial siswa. Padahal keterampilan sosial merupakan keterampilan dalam bermasyarakat, karena didalamnya mengisyaratkan tentang nilai- nilai dan norma yang ada di masyarakat. Salah satu pembelajaran sikap dan nilai yang dapat dilakukan adalah mellui teknik klarifikasi nilai (VCT). Melalui VCT ini diharapkan dapat mengukur kesdaran siswa akan nilai yang ada di masyarakat. Selain itu, melalui VCT guru dapat membantu siswa untuk mengungkapkan perasaanya melalui dialog secara terbuka dan bebas.
\end{abstract}

Cara Mengutip

Rachmadyanti, P, Rochani. (2017). Pengembangan Social Skill Siswa Sekolah Dasar melalui Teknik Pembelajaran VCT (Value Clarification Technique). DWIJACENDEKIA Jurnal Riset Pedagogik, 1(2), 70-78.
Korespondensi Penulis

putrirachmadyanti@unesa.ac.id
p-ISSN 2581-1843

e-ISSN 2581-1835 


\section{PENDAHULUAN}

Pendidikan merupakan aspek terpenting dalam menjamin Pendidikan dasar memiliki tugas dan peranan yang penting dalam mengembangkan 3 aspek kemampuan siswa, yaitu aspek kognitif, afektif, dan psikomotor. Ketiga aspek tersebut ditanamkan pada siswa melalui pembelajaran yang dilakukan oleh guru. Pembelajaran di SD saat ini tentunya mengacu pada kurikulum yang terbaru yaitu Kurikulum 2013 atau lazim disebut K-13. Berdasarkan paparan dari Kemdikbud bahwa tujuan akhir dari pembelajaran di SD hakikatnya adalah menanamkan aspek afektif (sikap) yang menjadi aspek utama. Hal ini berkebalikan dengan pendidikan tinggi yang lebih mendominasi aspek kognitif sebagai sasaran utama pembelajaran. Penanaman aspek sikap menjadi faktor yang terpenting di SD tersebut tentu tidak tanpa alasan. Hal ini mengingat pendidikan dasar merupakan peletak dasar dari karakter siswa untuk menjadi warga masyarakat, baik nasional maupun internasional.

Pembelajaran sikap dapat diperoleh siswa melalui pembelajaran yang dilakukan oleh guru, dibantu dengan adanya beberapa pilihan media pembelajaran sebagai pembantu dalam menyampaikan pesan. Masalah yang terjadi saat ini, kebanyakan guru seakan terlena dengan tuntutan penanmaan aspek sikap menjai yang dominan untuk pendidikan dasar. Para guru masih fokus dengan pengembangan kognitif siswa (pengetahuan) ditambah beban penerapan pendekatan tematik pada K-13 menambah rumitnya masalah pembelajaran sikap di tingkat SD. Hal ini akan berdampak pada output siswa yang dihasilkan, misalnya, bisa saja terjadi siswa pintar secara kognitif namun minim sikap toleransi dengan teman, pintar namun kurang sopan dengan Guru, ataupun sebaliknya. Oleh sebab itu, pembelajaran sikap tidak dapat dianggap sepele, perlu pemikiran yang serius untuk menangani masalah tersebut. Dampak jangka panjang dari kurang maksimalnya pembelajaran sikap yang diperoleh siswa akan mempengaruhi kehidupan sosial siswa kelak saat sudah dewasa. Untuk itu, perlu adanya paparan tentang bagaimana mengembangkan pembelajaran sikap bagi anak SD, agar dapat membantu para guru dan pemerhati pendidikan anak untuk lebih giat membelajarakan karakter pada anak SD.

\section{PEMBAHASAN}

\section{HAKIKAT KETERAMPILAN SOSIAL (SOCIAL SKILL) DI SEKOLAH DASAR}

IImu Pengetahuan Sosial (IPS) merupakan salah satu bahan materi ajar di SD, yang materinya bersumber dari ilmu- ilmu sosial (ekonomi, geografi, sosiologi, sejarah, antropologi), lingkungan, masyarakat, pengalaman, fenomena sosial, dan lain- lain. Ahmadi (2011: 9) mengungkapkan bahwa fungsi IPS sebagai pendidikan yaitu membekali siswa dengan pengetahuan sosial 
yang berguna untuk masa depannya, keterampilan sosial dan intelektual dalam membina perhatian serta kepedulian sosialnya sebagai Sumber daya manusia yang bertanggungjawab dalam merealisasikan tujuan pendidikan nasional.

Berkaitan dengan fungsi pembelajaran IPS, Summaatmadja (2005) mengetengahkan terhadap tuntutan munculnya sejumlah keterampilan yaitu keterampilan sosial meliputi kerja sama, bergotong royong , menolong orang lain. Gunansyah (2015: 9) menambahkan bahwa untuk domain sikap dan nilai, seorang warga negara diharapkan terdorong menjadi pribadi yang beriman, berakhklak mulia, percaya diri, bertanggungjawab, Hal ini tentunya mengarah pada paradigma untuk menumbuhkan orientasi siswa yang positif. Guru dapat menempatkan diri untuk memberi kebebasan siswa untuk memilih dan mengambil keputusan tentang nilai- nilai yang ada di masyarakat.

Salah satu model taksonomi ranah afektif adalah Taksonomi Ranah Afektif Krathwol. Model ini memberikan seperangkat kriteria untuk mengklasifikasi outcomes pendidikan pada ranah afektif. Bagi Krathwol, pembelajaran afektif ditunjukkan oleh perilaku - perilaku yang mengindikasikan sikap kesadaran, minat, perhatian, fokus, bertanggung jawab, kemampuan mendengarkan dan merespon selama berinteraksi dengan orang lain, serta kemampuan untuk menunjukkan karakteristik- karakteristik atau nilainilai dalam kehidupan nyata. Taksonomi Krathwol ini dapat diterapkan pada semua bidang dan level pembelajaran. Lima level taksonomi ranah afektif menurut Krathwol dipaparkan sebagai berikut.

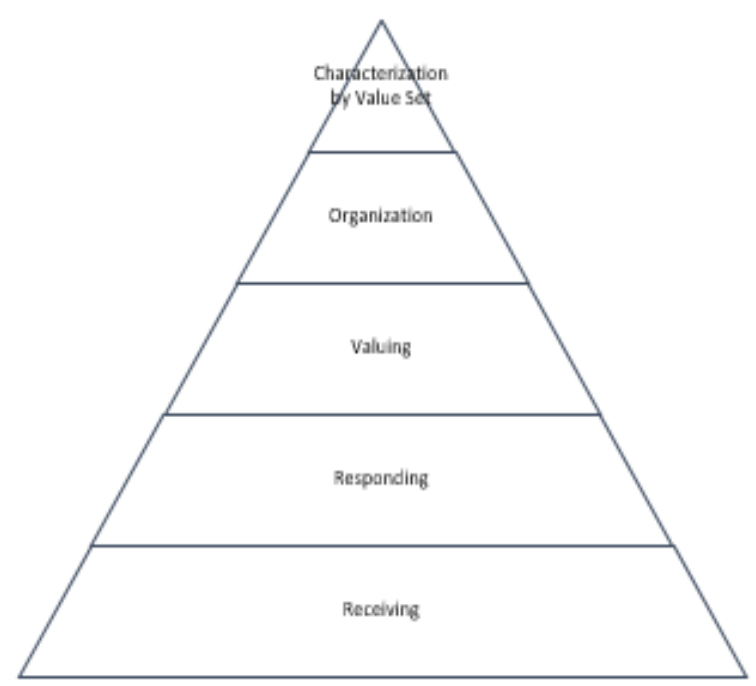

Gambar 1. Taksonomi Afektif Krathwol Sumber: Huda, 2013

\section{Menerima (Receiving)}

Pada level ini, siswa terlebih dahulu menyadari apa yang disajikan oleh guru dan siswa sellau ingin mencatat materi yang disampaikan guru. Pada tahap ini, guru sebagai penyedia stimulus dan presenter.

2. Merespons (Responding)

Setelah menerima stimulus, siswasiswa mulai meresponnya untuk memperoleh penemuan baru. Pada level ini,siswa mencari aktivitasaktivitas belajar dengan rasa puas Karena telah berhasil berpartisipasi di dalamnya.

3. Menghargai (Valuing)

Siswa- siswa membuat keputusan tentang nilai dan komitmennya untuk dan terlibat dalam nilai tersebut. Siswa membuat pilihan, dan ketika sudah menerima suatu nilai, berusaha untuk mengajak orang lain menuju niai yang dipilihnya.

\begin{tabular}{lrr} 
4. Mengatur (Organization) & \\
\multicolumn{2}{c}{ Langkah } & \multicolumn{2}{c}{ selanjutnya } \\
mengharuskan siswa & untuk \\
mengorganisasi nilai- & nilai & dan
\end{tabular}


mengkonstruksi suatu sistem yang dapat mengatur serangkaian sikap, kepercayaan, dan nilai- nilai dengan menghubungkannya antar satu sama lain.

5. Berkarakter dengan nilai (Characterization by Value Set)

Siswa- siswa pada level ini sudah mulai berusaha menginternalisasikan dan mengorganisasi nilai- nilai ke dalam suatu sistem dan dapat menerapkan nilai- nilai tersebut dalam kehidupan nyata.

Berkaitan dengan keterampilan sosial yang harus dimiliki oleh siswa, guru diharapkan dapat memberikan pelayanan pembelajaran yang dapat mengembangkan aspek tersebut. Keterampilan sosial mutlak diperlukan dalam pembelajara karena keterampilan sosial berkaitan dengan idup bermasyarakat. Combs dan Slaby (Sorionsong 2013: 26) mengemukakan bahwa ketermpilan sosial adalah kemampuan untuk berinteraksi dengan orang lain dalam konteks sosial dan cara yang dapat diterima, sedangkan Muhibin (2008:13) membedakan keterampilan sosial dengan perkembangan sosial dimana perkembangan sosial merupakan suatu proses pembentukan pribadi sosial yakni dalam keluarga, budaya dan bangsa sedangkan keterampilan sosial merupakan kemampuan seseorang untuk beradaptasi dengan lingkungan sosialnya.

Beberapa penelitian yang mengemukakan tentang pentingnya menumbuhkan keterampilan sosial pada anak, sebagai berikut ini. Isbayani, dkk (2015) yang meneliti tentang kegiatan outbond dapat meningkatkan keterampian sosial emosiaonal pada anak. Keterampilan sosial dalam penelitian ini dikategorikan sebagai kemampuan untuk berhubungan dengan orang lain yang menghasilkan suatu sikap dan perilaku, melalui pengalamna langsung. Selain itu, adapula penelitian yang dilakukan oleh Fajriyah (2014) tentang keefektifan pembelajaran kooperatif tipe Numberd Head Together untuk Mengembangkan Keterampilan Sosial Siswa SD. Dalam penelitian ini memfokusikan peningkatan keterampilan sosial dalam kerja sama tim atau kelompok. Sehingga mendapakan kesimpulan bahwa pembelajaran kooperatif tipe NHT efektif untuk mengembangkan keterampilan sosial siswa pada sekolah unggulan dan biasa. Berdasarkan kajian di atas, maka guru SD perlu untuk mengembangkan keterampilan sosial anak. $\mathrm{Hal}$ ini berkaitan dengan bekal kehidupan si anak di masa mendatang.

\section{MODEL PEMBELAJARAN VCT}

Model pembelajaran VCT (Value Clarification Technique) digunakan pertama kali oleh Louis Raths pada tahun 1950-an ketika mengajar di New York University. Model Pembelajaran VCT ini membantu siswa untuk menentukan suatu nilai / makna secara mendalam. Nilai merupakan standar untuk menentukan baik atau buruk, indah atau tidak indah. IPS sebagai salah satu matapelajaran yang diajarkan di SD memiliki tujuan yaitu membentuk warga negara yang baik, didalamnya mengandung nilai- nilai kehidupan yang harus diajarkan kepada siswa. Salah satu model pembelajaran yang dapat dilakukan untuk menanamkan nilai dan sikap yang baik bagi siswa adalah model pembelajaran VCT (Value Clarification Technique). 
Menurut Louis E. Raths dalam Siradjuddin ( 2012: 60) pendekatan pendidikan nilai didasarkan pada tujuh langkah proses menilai, yaitu : a) memilih dengan bebas; memilih dari antara alternatif- alternatif, b) setelah mempertimbangkan rintangan yang ada; c) memilih setelah pertimbangan yang mendalam konsekuensikonsekuensi yang mungkin dari masing- masing alternative; d) menjunjung dan menghargai pilihan yang dipertimbangkannya paling penting dan paling berharga; e) meyakini kebenaran nilai yang dipilihnya; f) bertingkah laku konsisten dengan nilai yang dipilihnya; g) bertingkah laku secara berulangulang konsisten dengan nilai yang dipilihnya.

Siswandi, (2009: mengemukakan bahwa value Clarification Technique, merupakan sebuah cara bagaimana menanamkan dan menggali/ mengungkapkan nilainilai tertentu dari diri peserta didik. Oleh karena itu, pada prosesnya VCT berfungsi untuk: a) mengukur atau mengetahui tingkat kesadaran siswa tentang suatu nilai; b) membina kesadaran siswa tentang nilai-nilai yang dimilikinya baik yang positif maupun yang negatif untuk kemudian dibina kearah peningkatan atau pembetulannya; c) menanamkan suatu nilai kepada siswa melalui cara yang rasional dan diterima siswa sebagai milik pribadinya.

Kirsschenbaum dalam (Darmadi: 123) menyatakan bahwa manusia pada dasarnya merupakan makhluk yang terdidik dan bisa ddiidik, sehingga dalam hidupnya mansuia senantiasa memerlukan nilai sebagai pegangan dalam menyikapi dunia dan kehidupannya. Sehingga pendidikan nilai itu mutlak diperlukan, khsuusnya menyangkut proses klarifikasi nilainilai keyakinan dan kehidupan yang layak bagi diri mansuia itu sendiri. Menurut Kirchenbaum, klarifikasi nilai bukanlah "value-free" atau relativistic, melainkan mellaui suatu proses pengggetaran potensi afektual yang melibatkan segenap potensi mansia. Berikut gambaran mengenai klarifikasi nilai dan kerangka teoritis tentang Value Clarification.

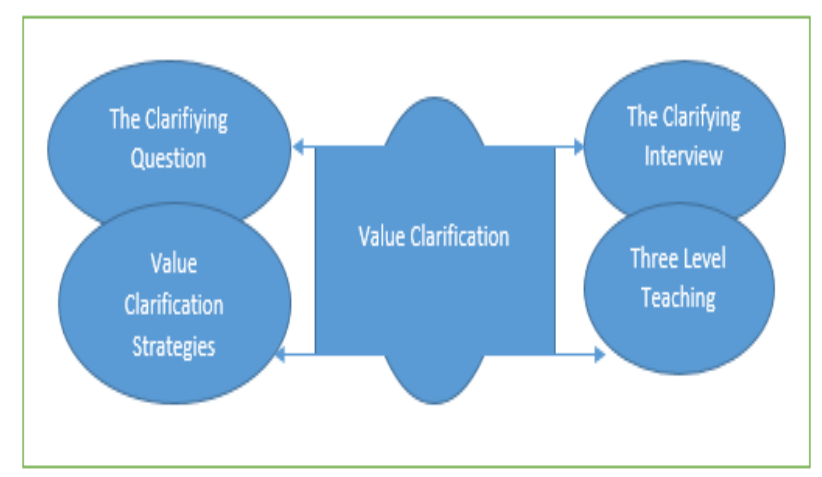

Gambar 2. Gambaran tentang Teknik Klarifikasi Nilai (Darmadi, 2007: 124)

Keterpaduan ketiga gambaran di atas akan melahirkan sebuah totalitas dalam pendidikan yakni totalitas diri yang utuh untuk mengembangkan ketiga domain yaitu kognitif, afektif, psikomotor. Penanaman sosial yang baik dapat dikembangkan oleh guru dengan mengajak siswa memahami dari permasalahan- permasalahan sosial di masyarakat sehingga akan diharapkan dapat mengkalirifikasi nilai- nilai yang ada di masyarakat.

Model pembelajaran VCT pada dasarnya bersifat induktif, berangkat dari pengalaman- pengalaman kelompok menuju ide yang umum tentang pengetahuan dan kesadaran diri. Secara sederhana, guru dapat mengarahkan siswa untuk belajar secara berkelompok kemudian siswa dapat membandingkan dengan pengalaman siswa. Guru berperan 
dalam membantu siswa dalam memperoleh kesadaran tentang nilai yang mereka miliki. Taniredja, (2011:89) mengemukakan pendapat bahwa terdapat lima prinsipprisip VCT, yaitu: a) Penanaman nilai dan pengubahan sikap dipengaruhi banyak faktor antara lain faktor potensi diri, kepekaan emosi, intelektual dan faktor lingkungan, norma nilai masyarakat, sistem pendidikan dan lingkungan keluarga dan lingkungan bermain; b) sikap dan perubahan sikap dipengaruhi oleh stimulus yang diterima siswa dan kekuatan nilai yang telah tertanam atau dimiliki pada diri siswa; c) nilai, moral dan norma dipengaruhi oleh faktor perkembangan, sehingga guru harus mempertimbangkan tingkat perkembangan moral (moral development) dari setiap siswa. Tingkat perkembangan moral untuk siswa dipengaruhi oleh usia dan pengaruh lingkungan terutama lingkungan sosial; d) pengubahan sikap dan nilai memerlukan keterampilan mengklarifikasi nilai/sikap secara rasional, sehingga dalam diri siswa muncul kesadaran diri bukan karena rasa kewajiban bersikap tertentu atau berbuat tertentu; e) pengubahan nilai memerlukan keterbukaan, karena itu pembelajran melaluiVCT menuntut keterbukaan antara guru dan siswa

Paparan tentang pembelajaran VCT di atas tentunya memerlukan peran guru sebagai motivator. Guru harus dapat memotivasi siswa untuk berfikir, refleksi diri serta berani mengungkapkan perasaannya. Bahkan menurut Suprijono (2009: 164) dalam perspketif humanis, motivasi mengarahkan pada kapasitas siswa untuk mengembangkan kepribadian dan kebebasan untuk memilih nasib mereka. Arifah (2016: 86) menambahkan bahwa memotivasi berbeda dengan menasihati, meotivasi dimulai dengan sapaan hangat dan berkonsentrasi untuk mendengarkan apa yang dikatakan oleh siswa. Hasilnya, siswa akan merasa bahwa keberadaanya spesial di mata guru.

\section{PENGEMBANGAN SOCIAL SKILL SISWA SD MELALUI TEKNIK PEMBELAJARAN VCT}

Sekolah dasar sebagai salah satu lembaga formal penting dalam pendidikan dasar, tidak hanya berperan dalam mengembangkan kognitif anak atau keterampilan akademik, tetapi juga harus mengembangkan ketrampilan sosial dan emosi. Hal ini sejalan dengan pendapat Yustiana dalam Kurniati (2011: 1) bawa kemampuan dasar yang harus dimiliki anak tidak terbatas pada kemampuan membaca, menulis, berhitung tetapi juga kemampuan pribadi dan sosial. Sanjaya (2006: 284) menambahkan bahwa proses pendidikan bukan hanay membentuk kecerdasan atau keterampilan tertentu saa, namun juga membentuk dan mengembangkan sikap agar anak berperilaku sesuai norma yang berlaku di masyarakat.

Salah satu karakteristik VCT sebagai suatu model pembelajaran sikap adalah proses analisis nilai yang sudah ada sebelumnya dalam diri siswa kemudian menyelaraskan dengan nilai- nilai baru yang hendak ditanamkan.

Model Pembelajaran Value Clarification Technique (VCT) mempunyai sintak pembelajaran tabel 1. 


Tabel 1.
Pembelajaran Value
Technique (VCT)

Dalam implmentasi VCT, dikembangkan melalui dialog dengan siswa yang berlangsung dalam suasana santai dan terbuka. Hal ini dilakukan agar siswa dengan bebas mengungkapkan pendapatnya tentang analisis nilai di masyarakat. Menurut Sanjaya (2006 : 283) Adapun beberapa hal yang harus diperhatikan guru dalam mengimplementasikan VCT melalui proses dialog, yaitu (1) menghindari penyamaian pesan melalui proses pemberian nasehat / memberikan pesan- pesan moral yang menurut guru baik; (2) tidak memaksakan siswa untk memberi respon apablia memang siswa tidak menhendakinya; (3) tidak mendesak siswa pada pendirian tertentu; (4) menghindari respon yang menyebabkan siswa terpojok; (5) membuat dialog terlaksana dengan bebas dan terbuka agar siswa dapat dengan uur mengungkapkan perasaannya.

Aspek keterbukaan dalam pembelajaran memiliki berbagai manfaat, salah satunya adalah mempererat hubungan siswa dengan guru. Interaksi yang dimaksudkan disini adalah interaksi yang terjadi antara guru dan siswa dengan pola interaksi yang hangat namun tetap menjunjung etika. Siswa tidak takut dalam mengemukakan pendapat serta memotivasi siswa untuk selalu berani berargumen. Kunci guru yang baik adalah guru yang mampu memahami siswa dan mampu mengembangkan segala potensi yang ada pada diri siswa. Guru harus menghargai setiap argument yang dikemukakan oleh siswa karena salah satu tugas guru adalah menjadi pendengar yang baik. Guru tidak harus selalu memaksakan siswa untuk berpendapat sama dengan argument yang dimiliki oleh 
sang guru. Guru hanya perlu untuk memberikan penanaman dan penguatan tentang nilai - nilai kebaikan yang ada di masyarakat.

Pembelajaran berbasis VCT ini pada hakikatnya dapat diaplikasikan pada berbagai mata pelajaran, khususnya dalam rangka membantu siswa dalam memahami sebuah nilai di masyarakat atau dalam hal ini berkaitan dengan pembelajaran moral. Pembelaran moral yang berhasil, tentunya diharapkan dapat membentuk karakter siswa yang baik pula. Siswa era kini tidak cukup hanya pandai secara kognitif, namun perlu penguatan dalam aspek siskap mengingat berbagai kasus yang trejadi di masyarakat adalah akibat dari adanya kemajuan IPTEK. Sehingga tidak dapat dipungkiri bahwa guru adalah agen pembaharu, fasilitator dan motivator yang harus juga berjiwa unggul untuk membentuk siswa yang berkarakter dan berbudi luhur.

\section{KESIMPULAN}

Value Clarification Technique (VCT) nilai tersebut dipahami dan merupakan salah satu alternatif dilaksanakan dalam kehidupan seharipilihan guru dalam mengembangkan hari. Peran guru amat diperlukan sikap siswa, salah satunya dalam melatih habituasi siswa sebagai keterampilan sosial. Pembelajaran bentuk pengembangan dari berbasis VCT mengedepankan pembelajaran di kelas yang telah keterbukaan siswa dalam memberikan dilakukan. Motivasi yang diberikan pilihan- pilihan

siswa serta analsiis siswa terhadap nilai- nilai dalam masyarakay. Sehingga siswa dapat lebih memahami dan menyadari pentingnya oleh guru diharapkan dapat emmberikan dampak postif bagi siswa dalam rangka memupuk rasa kepedulian siswa terhadap lingkungan atau masyarakat.

\section{DAFTAR PUSTAKA}

Ahmadi, lif Khoiru dan Sofan Amri. 2011. Mengembangkan Pemelaaran IPS Terpadu. Jakarta: Prestasi Pustaka Publisher.

Arifah, Fita Nur. 2016. Menjadi Guru Teladan, Kreatif, Inspiratif, Motivatif, \& Profesional. Yogyakarta: Araska.

Darmadi, Hamid. 2007. Dasar Konsep Pendidikan Moral. Bandung: Alfabeta.
Djajari. 2012. Model Pembelajaran Inovatif dan Proses Pembelajaran Konvensional. Jakarta: Balai Pustaka.

Fajriyah, Khusnul. 2014. Keefektifan Pembelajaran Kooperatif Tipe Numbered Head Together untuk Mengembangkan Keterampilan Sosial Siswa SD. Jurnal Majalah IImiah Pendidikan Dasar Volume 4 Nomor 2 Desember 2014 Universitas PGRI Semarang. 
Gunansyah, Ganes. 2015. Pendidikan IPS Berorientasi Praktik yang Baik. Surabaya: Unesa University Press.

Huda, Miftahul. 2013. Model - model Pengajaran dan Pembelajaran (isu - Isu Metodis dan Paradigmatis). Yogyakarta: Pustaka Belajar.

Isbayani, dkk. 2015. Penerapan Metode Outbond untuk Meningkatkan Keterampilan Sosial Emosional Anak. eJournal PG PAUD Universitas Pendidikan Ganesha Jurusan Pendidikan Guru Pendidikan Anak Usia Dini (Volume 3 No.1 - Tahun 2015)
Kurniati Euis. 2011. Program Bimbingan untuk Mengembangkan Keterampilan Sosial Anak melalui Permainan Tradisional. Jurnal Pedogogia hal 97-214 Universitas Pendidikan Indonesia.

Sanjaya, Wina. 2006. Strategi Pembelajaran Berorientasi Standar Proses Pendidikan. Jakarta: Kencana Prenada Media Grup.

Suprijono, Agus. 2009. Cooperative Learning Teiri \& Aplikasi Paikem. Yogyakarta: Pustaka Pelajar 